\title{
PENERAPAN METODE KOMUNIKASI OLEH PENYULUH PERTANIAN PADA KELOMPOK TANI GEMAH RIFAH I DESA JAMUR LABU KECAMATAN RANTAU ACEH TAMIANG
}

\author{
Kamaruzzaman \\ Universitas Sumatera Utara \\ rkamaruz@gmail.com
}

\begin{abstract}
Abstrak
Pengembangan kelompoktani dewasa ini mengalami kemerosotan karena pengaruh globalisasi dan otonomi daerah. Selain itu, terjadi diskomunikasi antara Penyuluh pertanian dengan kelompoktani menyebabkan penerapan metode penyuluhan tidak efektif. Oleh karena itu penelitian ini bertujuan untuk mengetahui penerapan metode komunikasi penyuluhan pertanian yang efektif Kelompoktani Gemah Rifah I Desa Jamur Labu Kecamatan Rantau Kabupaten Aceh Tamiang. Penelitian ini menggunakan studi kasus karena faktor karakteristik, geografis dan latar belakang petani berbeda dengan daerah lain. Responden dalam penelitian ini berjumlah 6 orang. Hasil dari penelitian ini menunjukkan bahwa penerapan metode komunikasi oleh penyuluh pertanian dominan dengan cara pendekatan kelompok dengan cara membuat pertemuan rutin. Metode komunikasi penyuluhan pertanian dengan pertemuan kelompok dianggap lebih efektif karena karakteristik kelompoktani dengan kekompakan sangat tinggi dan mudah berkumpul. Temuan penting lainnya dalam penelitian ini dimana pada kelompoktani dengan kelas kelompok tinggi, maka metode penyuluhan dengan pendekatan kelompok dalam dengan cara pertemuan kelompok rutin sangat efektif untuk pengembangan usaha agribisnis petani.
\end{abstract}

Kata kunci: Penyuluhan, Metode Komunikasi, Kelompoktani

\begin{abstract}
The existence of Kelompoktani has been declined due to the effects of globalization and regional autonomy. Besides, discommunications between agricultural extension agent with Kelompoktani led to ineffective adoption of extension methods. Therefore, this study aims to determine the implementation of effective communication methods in agricultural extension of Kelompoktani Gemah Rifah I Jamur Labu Village Rantau, Aceh Tamiang. This research used a case study because of different characteristics, geographical and background of the peasants. There are 6 respondents in this study. The results of this study indicate that the implementation of communication methods by dominant agricultural extension is by approaching the group- making regular meetings. This method of communication was considered more effective because Kelompoktani characteristics were very bonding and easy to assemble. Other key findings in the study is that the kelompoktani with high-grade group, the extension method by group appraoach in the way of regular group meetings are very effective for the development of peasants agribusiness.
\end{abstract}

Keywords: Counseling, Communication Methods, kelompoktani 


\section{PENDAHULUAN}

Salah satu sektor handalan untuk kontribusi pembangunan nasional adalah sektor pertanian. Peran sektor pertanian diantaranya membuka lapangan pekerjaan, menyumbang Produk Domestik Bruto (PDB), sumber devisa, bahan baku industri, sumber bahan pangan dan gizi, serta pendorong bergeraknya sektor-sektor ekonomi kreatif lainya. Kenyataannya di era otonomi daerah peran sektor ini semakin kurang jika dibandingkan potensi sumber daya alam yang tersedia tidak sebanding dengan sumber daya manusia

Sejak dilimpahkan sebagian wewenang pusat ke daerah melalui otonomi daerah mulai tahun 1999 (mengalami revisi terakhir tahun 2014) sampai saat ini arah pembangunan pertanian daerah sangat beragam. Ada daerah mengalami kemajuan dan tidak sedikit daerah mengalami hal sebaliknya. Sebagian wewenang pusat terhadap sektor pertanian juga tidak terarah seiring bergantinya pucuk kepresidenan di Jakarta. Berbagai pertimbangan dan kepentingan arah kebijakan sektor pertanian dengan mudah berubah-berubah.

Akibatnya telah terjadi kebingungan semua kalangan diantaranya pelaku utama dan pelaku usaha karena ketidakpastian masa depan usahanya. Kalangan investor enggan menanam modal jangka panjang karena hal yang sama. Permasalah tersebut terus terjadi sehingga kondisi saat ini infrastruktur pertanian terbatas dan terabaikan, nilai tambah dan harga produk pertanian rendah, ketersediaan sumber daya manusia pengelola pertanian terbatas, struktur pasar yang monopsonis dan penguasaan dan akses teknologi pertanian lemah.

Salah satu masalah jadi sorotan dalam penelitian yaitu akses teknologi pertanian lemah, dimana tingkat pendidikan petani yang sebagian besar masih rendah menyebabkan sistem alih teknologi lemah dan penerapan teknologi kurang tepat sasaran. Lemahnya sumber daya manusia akibat dari paradigma kebijakan penganggaran pemerintah daeah masih mementingkan pembangunan fisik dengan mengabaikan pembangunan sumber daya manusia. Sebuah tantangan tersendiri bagi para penyuluh pertanian menghadapi hal ini, dengan mengedepankan optimisme dan berbesar hati ingin mengulangi masa kejayaan era dimana berkat sinerji pemerintah dalam mendukung penyuluhan tercapainya swasembada pangan.

Dukungan pemerintah saat ini terhadap penyuluh tidak hanya melihat sejauh mana jumlah penyuluh sudah terpenuhi tetapi juga pemerintah harus memahami secara keseluruhan bagaimana memfungsikan penyuluhan pertanian dalam langkah strategis pembangunan dengan dukungan dana yang memadai. Terlepas dari peranan pemerintah, penyuluh sendiri juga melakukan inovasi pelaksanaan penyuluhan dalam menyampaikan materi dan alat peraga menggunkana tehnik atau cara yang diterima petani dan sesuai dengan perkembangan zaman.

Sementara itu, secara harfiah menurut Zulkarimen Nasution (2002), penyuluhan bersumber dari kata suluh yang berarti obor atau alat untuk menerangi keadaan yang gelap. Kata menerangi ini bermakna sebagai petunjuk bagi masyarakat dari tidak tahu menjadi tau dan mengerti, dari mengerti menjadi lebih mengerti lagi sehingga dapat melakukannya. Definis tersebut dapat kita gambarkan secara tehnis, bahwa penyuluh mengarahkan petani melaksanakan adopsi inovasi pertanian untuk memproduksi produk pangan setinggi-tingginya. Untuk keberhasilan tersebut maka perlu ada suatu tehnik atau cara dalam bentuk metode komunikasi 
kegiatan penyuluhan yang tepat, sehingga metode komunikasi penyuluhan ini nanti menjadi sebuah model baru bagi daerah lain untuk diterapkan dalam kelompoktani.

Sebagaimana diketahui kegiatan penyuluhan pertanian mengalamai proses komunikasi pengiriman pesan atau informasi oleh komunikator atau penyuluh kepada komunikan atau petani tetapi dalam proses pengiriman tersebut dibutuhkan suatu keterampilan dalam memaknai pesan baik oleh komunikator ataupun komunikan sehingga dapat membuat sukses pertukaran informasi.

Berdasarkan pengamatan dan pengalaman penulis alami selaku Penyuluhan di Kabupaten Aceh Tamiang, sesungguhnya apa yang selama ini dilakukan oleh penyuluh kepada Kelompoktani sudah benar dan telah mengikuti prosedur-prosedur yang telah ditetapkan, sehingga sebagian kelompoktani binaan berhasil mandiri seperti kelompoktani Gemah Rifah I dan ada juga yang belum berhasil mandiri karena kurangnya pemahaman penyuluh terhadap karakter, tradisi serta kebiasaan masyarakat setempat. Ketika membuat program penyuluhan dan dalam menerapkan metode penyuluhan tidak tepat dan tidak maksimal.

Untuk menyikapi permasalahan dan fenomena-fenomena di atas, maka penulis tertarik untuk mengkaji secara ilmiah dalam sebuah penelitian tentang proses penerapan metode komunikasi yang tepat berhubungan metode penyuluhan pertanian dan ingin mengetahui faktor-faktor dalam penentuan metode penyuluhan pada Kelompoktani di Aceh Tamiang khususnya pada Kelompoktani Gemah Rifah I Desa Jamur Labu Kecamatan Rantau.

Adapun fokus penelitian ini adalah penerapan metode komunikasi penyuluh yang tepat oleh penyuluh pertanian di kelompoktani Gemah Rifah I dan faktor penentu penerapan metode komunikasi penyuluhan selama ini berlangsung sehingga Kelompoktani Gemah Rifah I berhasil dengan meraih gelar Kelompoktani kelas Madya. Maka hal yang ingin dilihat adalah: 1) Bagaimana penerapan metode penyuluhan pertanian yang efektif dilaksanakan oleh penyuluh pertanian di kelompoktani Gemah Rifah I, dan 2) Faktor-faktor apa sajakah dalam pemilihan metode penyuluh pertanian di kelompoktani Gemah Rifah I.

\section{METODOLOGI PENELITIAN}

Penelitian ini menggunakan pendekatan kualitatif. Bogdan dan Taylor (dalam Moleong, 1975) mendefinisikan metodologi kualitatif sebagai prosedur penelitian yang menghasilkan data deskriptif berupa kata-kata tertulis atau lisan dari orang-orang dan perilaku yang dapat diamati. Pendekatan ini diarahkan pada latar dari individu tersebut secara holistik (utuh). Peneliti tidak mengisolasikan individu atau organisasi ke dalam variabel atau hipotesis, tapi perlu memandangnya sebagai bagian dari suatu keutuhan.

Aspek Kajian dalam penelitian ini meliputi; 1) persiapan penyuluhan, 2) metode penyuluhan pertanian, dan 3) faktor penentuan metode penyuluhan pertanian

Penelitian ini dilakukan pada Kelompoktani Gemah Fifah I Desa Jamur Labu Kecamatan Rantau Kabupaten Aceh Tamiang. Kelompoktani ini berada dalam binaan Petugas Penyuluh Pertanian (PPL) Kecamatan Rantau. PPL mempunyai tugas dalam pemberdayaan kelompoktani dalam hal menyampaikan adopsi inovasi pertanian sehingga usaha tani anggota kelompok mengarah kepola usaha agribisnis. 
Adapun ciri dan karekteristik yang digunakan Sarantakos, 1993 (dalam Poerwandari, 2005), yaitu;

- Anggota kelompok tani Gemah Fifah I

- Berdomisili di Desa Jamur Labu

- Masih mengikuti kegiatan kelompok

- Anggota yang aktif dalam pembinaan penyuluh setempat

- Anggota yang sudah lama menjadi anggota kelompok.

Pengumpulan data dilakukan dengan melakukan wawancara. Ini karena flexibilitasnya yang tinggi, dimana jawaban yang diberikan oleh narasumber berkembang sehingga akan didapat informasi yang lebih lugas dan lengkap. Peneliti juga mempunyai kebebasan mengembangkan pertanyaannya hingga tuntas, dan saat menemukan hal yang belum jelas dapat digali lebih dalam maupun dikonfirmasi ulang. Selain itu, data yang dikumpulkan mampu menggambarkan konteks sosialnya.

Observasi juga dilakukan untuk memperkaya data. Dalam penelitian ini, observasi dilakukan pada saat wawancara dan menggunakan narasumber lain yaitu Ketua kelompok tani, anggota kelompok tani, PPL , Kantor BPP Rantau dan Saung Tani selaku tempat penyuluhan berlangsung dan informasi lainnya mengenai kegiatan penyuluhan pertanian di Kelompoktani Gemah Rifah I

Analisis data kualitatif dilakukan apabila data empiris yang diperoleh adalah data kualitatif berupa kumpulan berwujud kata-kata dan bukan rangkaian angka serta tidak dapat disusun dalam kategorikategori/struktur klasifikasi. Data bisa saja dikumpulkan dalam aneka macam cara (observasi, wawancara, intisari dokumen, pita rekaman) dan biasanya diproses terlebih dahulu sebelum siap digunakan (melalui pencatatan, pengetikan, penyuntingan, atau alih-tulis), tetapi analisis kualitatif tetap menggunakan kata-kata yang biasanya disusun ke dalam teks yang diperluas, dan tidak menggunakan perhitungan matematis atau statistika sebagai alat bantu analisis.

$$
\text { Adapaun analisis data yang }
$$
dilakukan dalam penelitian ini adalah; 1) reduksi data, 2) penyajian data atau display data, 3) trianggulasi data, dan 4) menarik kesimpulan.

\section{HASIL DAN PEMBAHASAN}

Metode komunikasi dalam penyuluhan pertanian merupakan bagian dari proses penyampaian informasi kepada sasaran dalam pencapaian tujuan yang ingin dicapai (Mardikanto, 2009). Metode komunikasi yang dilaksanakan oleh Petugas Penyuluhan Pertanian (PPL) dengan kombinasi beberapa metode penyuluhan yang efektif untuk mencapai tujuan penyuluhan pertanian.

Hal ini dapat dilihat dari adanya jadwal kunjungan lapangan PPL menggunakan sistem Latihan Dan Kunjungan (LAKU) yang jelas dari rencana tahunan kerja PPL dalam Wilayah Kerja Penyuluh Pertanian (WKPP). Sebagaimana disampaikan oleh (Abbas, 1999), Penyuluh Pertanian Lapangan (PPL) yaitu penyuluh pertanian yang berhubungan langsung dengan petani beserta keluarganya menjadi tugas pokok sebagai pelaksanaan kegiatan penyuluhan dan WKPP berdasarkan program penyuluhan pertanian. Sebagai realisasi programa penyuluhan tersebut disusun beberapa pertimbangan metode penyuluhan untuk mencapai maksud tersebut.

Penerapan metode penyuluhan di kelompoktani Gemah Rifah I sudah dilaksanakan dengan sedemikian rupa sehingga sampai saat ini kelompok tersbut sudah maju, bukti kemajuan kelompok ini 
sudah dijelaskan pada bab sebelumnya. Adapun metode yang berhasil peneliti indentifikasi yang merupakan proses komunikasi efektif dalam kelompoktani kususnya di Kelompoktani Gemah Rifah I.

\section{Persiapan Penyuluhan Kelompoktani Gemah Rifah I}

Persiapan kegiatan penyuluhan di Kelompoktani Gemah Rifah I telah dilaksanakan dengan pertimbangan berbagai jenis metode penyuluhan yang tepat, efektif dan efisien guna mendukung Pemerintah Daerah Kabupaten Aceh Tamiang dalam pembangunan sumber daya manusia (SDM) petani. Seluruh rangkaian metode penyuluhan dirancang menjadi menarik agar dapat menjadi daya tarik anggota kelompoktani untuk selalu mengikuti penyuluhan. Perihal Metode penyuluhan merupakan suatu hal yang ikut berperan dalam mempengaruhi kecepatan adopsi dan difusi inovasi. Penggunaan metode yang efektif akan mempermudah untuk dipahami oleh petani. Metode penyuluhan sangat diperlukan agar pesan inovasi dari kegiatan penyuluhan dapat diterima dan diaplikasikan oleh target atau penerima manfaat (Musyafakat, 2005).

Belajar dari pengalaman, fenomena di lapangan masih menggambarkan lemahnya proses komunikasi dalam penyuluhan pertanian dilihat dari dampak yang ada. Purwanto (2009) menyampaikan bahwa ada empat masalah yang menghambat komunikasi dalam penyuluhan pertanian, baik oleh pengirim pesan (penyuluh pertanian) dan penerima pesan (petani). Empat faktor tersebut adalah: (a) masalah dalam penyampaian pesan; (b) masalah dalam pengembangan pesan; (c) masalah dalam menerima pesan; dan (d) masalah dalam menafsirkan pesan.

Bedasarkan hasil wawancara dengan informan adalah PPL Kelompoktani Gemah
Rifah I, alat bantu dan alat peraaga dalam menunjang kegiatan penyuluhan adalah sebagai berikut;

1. Lembaran persiapan penyuluhan

Berupa lembar persiapan menyuluh (LPM), lembar persiapan latihan (LPL), lembar persiapan kerja (LPK) dan Laporan Hasil Menyuluh (LHM)

2. Alat tulis

PPL yang bertugas di Kelompoktani Gemah Rifah I membawa alat tulis yang beragam warna baik itu kapur berwarna, pensil berwarna, bolpen dan spidol dsb.

3. Projektor

Jenis projektor yang digunakan oleh PPL yang bertugas di Kelompoktani Gemah Rifah I yaitu Movie projektor, untuk memproyeksikan film penyuluhan.

\section{Peta Singkap}

Peta singkap adalah sekumpulan poster selebar kertas koran, yang digabungkan menjadi satu. Peta singkap yang sering dibawakan oleh PPL adalah peta singkap padi, jagung dan kedelai. Penyebaran materi menggunakan peta singkap ini bertujuan untuk menjelaskan suatu proses atau rangkaian kegiatan yang berkaitan dengan pertanian secara sistematis.Penyebaran materi penyuluhan melalui peta singkap ini akan efekif, bila disampaikan kepada kelopoktani dengan anggota antara 5-35 orang.

Metode penyebaran penyuluhan melalui petasingkap ini mempunyai keunggulan. Keunggulan dari peta singkap ini diantaranya adalah ; 1) Dapat menjelaskan kepada hadirin tanpa membelakangi; 2) Bisa membangun cerita yang menarik melalui gambar sehingga lebih mudah difahami; 3) Dapat menampilkan proses/kegiatan secara terpisah-pisah; 4) Mudah digunakan tanpa bantuan peralatan lain. 


\section{Metode Penyuluhan Kelompoktani Gemah Rifah I}

Penelitian terdahulu dari Risyart A. Far Far (2014), yang meneliti tentang "Respons Petani Terhadap Penerapan Metode Penyuluhan Pertanian Di Kota Ambon Provinsi Maluku", menyatakan bahwa respons Petani terhadap metode yang digunakan dalam penyuluhan pertanian lebih banyak menggunakan metode pendekatan secara kelompok karena lebih efisien dari pada metode pendekatan perorangan dan metode pendekatan massal; dan faktor-faktor yang berpengaruh dalam penerapan metode penyuluhan yaitu ketersediaan sarana-sarana produksi, ketersediaan tenaga penyuluh, dan ketersediaan lapangan pekerjaan.

Pada keyataannya kemajuan usaha petani Gemah Rifah I sangat jelas terlihat mengalami perubahan dan pengembangan yang signifikan. Melalui hasil pengamatan peneliti tingkat pendapatan ekonomi masing-masing anggota sudah diatas sederhana. Dimana petani di Jamur Labu pola usahanya tidak lagi pada satu jenis komoditi saja tetapi lebih dari satu jenis usaha dijalani setiap harinya. Mulai dari sawah, kebun, ternak dan perikanan. Perkembangan pola usaha tani seperti Seperti dikemukakan oleh Suparta (2001) Keberhasilan agribisnis petani dapat dilihat pada tingkatan capaian kemajuan perilaku usaha petani., perilaku agribisnis dapat diukur dari: (1) aspek perilaku teknis produksi, yakni: unsur panca usaha; (2) aspek perilaku manajemen agribisnis, yakni: perencanaan agribisnis, pemanfaatan sumber daya agribisnis, meningkatkan efisiensi, meningkatkan produktivitas, senantiasa memperbaiki mutu hasil, melakukan perekayasaaan teknis produksi, melakukan fungsi kelembagaan agribisnis, dan selalu mengutamakan ketepatan dan kecepatan pelayanan; dan (3) aspek perilaku hubungan sistem agribisnis, yakni: melakukan hubungan kebersamaan dan saling ketergantungan dengan perusahaan agribisnis lainnya, melakukan kerjasama secara harmonis, dan aktif melakukan komunikasi informasi agribisnis.

Menurut hasil wawancara dan observasi peneliti kepada semua informan tingkat pendidikan anggota Kelompoktani setara sekolah menengah umum (SMU), hal ini berpengaruh pada penentuan metode penyuluhan dimana tingkat pengetahuan anggota kelompok dari kemampuan menulis dan membaca terhadap penentuan metode penyuluhan. PPL dalam pertemuan Kelompoktani Gemah Rifah I menggunakan materi terbaru tidak bersifat mengajarkan kepada petani pemula. Sebagian besar petani Gemah Rifah I tingkat usahanya sudah pada level anggota Kelompoktani kelas utama.

Metode pendekatan kelompok dirasakan menjadi sebuah indikasi keberhasilan usaha tani anggota Kelompoktani Gemah Rifah I. Dari semua informan yang peneliti wawancarai metode yang dominan dilaksanakan oleh PPL adalah pertemuan kelompok rutin. Secara teknis keterampilan bertani, anggota Kelompoktani sudah berhasil. Hal ini dikarenakan usia Kelompoktani sudah lama dan berbagai macam teknologi pertanian yang cocok diterapkan dikelompok sudah diberikan dan diterapkan oleh Anggota Kelompoktani. Salah satu tehnologi yang sudah berhasil adalah sistem tanam padi LEGOWO 2:1 dimana anggota Kelompoktani sudah merasakan manfaatnya sekarang dan banyak kelompok lain studi banding pada kelompoktani Gemah Rifah I.

Dilihat dari fenomena diatas maka ada perbedaan pernyataan penelitian terdahulu dengan hasil penelitian ini. Marliati, Sumardjo, dkk (2008) 
penelitiannya menunjukkan bahwa petani berada pada usia produktif dan pengalaman agribisnis cukup lama, namun belum ditunjang oleh pendidikan formal dan non formal yang tinggi serta belum didukung oleh luas penguasaan lahan pertanian yang memadai dan tingkat kinerja penyuluh pertanian dalam memberdayakan petani relatif belum baik (kategori "cukup"), hal ini disebabkan oleh faktor-faktor yang berpengaruh nyata terhadap kinerja.

Sedangkan temuan penting dalam penelitian ini adalah dimana pada kelompoktani dengan kelas kelompok tinggi, maka metode penyuluhan dengan pendekatan kelompok dengan cara pertamuan rutin sangat efektif untuk pengembangan agribisnis. Dasar dari pertimbangan pernyataan ini bahwa kelompoktani Gemah Rifah I berada pada kelas kelompok utama, dimana secara umum anggota kelompoktani memiliki pengalaman usaha tani yang cukup lama, dan pendidikan formal tidak begitu tinggi. Peningkatan wawasan agribisnis dan pengetahuan lain didapat dari pendidikan informal dari PPL dan pihak lain dan dapat meningkatkan pengembangan usahataninya.

\section{Faktor Pemilihan Metode dan konten materi Penyuluhan Kelompoktani Gemah Rifah I}

Masyarakat tani Indonesia terdapat berbagai macam suku, adat, budaya dan agama. Keragaman ini mendorong terjadinya pemilihan metode penyampaian informasi teknologi pertanian dengan melihat faktor-faktor keragaman diatas. Sedikit saja kesalahan dalam pemilihan metode penyuluhan dengan mengabaikan faktor kerangaman latar belakang petani, maka terjadi komunikasi yang tidak efektif. Bisa dibayangkan jika metode dan konten materi yang disampaikan tidak sesuai dengan nilai-nilai norma masyarakat setempat justru PPL akan dibenci oleh petani tersebut. Seperti hal nya dalam penelitian ini terdapat pertanyaan tentang foktor yang mempengaruhi penentuan penerapan metode penyuluhan yang terjadi di kelompoktani Gemah Rifah I.

Ban, van den, dkk (1980), menyatakan dalam masyarakat multiras, kelompok etnis harus ditargetkan terpisah karena karakteristik sosial dan budaya yang berbeda. bahasa, jenis makanan, dan agama adalah beberapa karakteristik etnis. Dalam hal dimana terdapat kelompok etnis berbeda di wilayah kerja penyuluhan pada wilayah atau zona yang sama, program penyuluhan harus mencerminkan perbedaan ini.

Pemilihan metode penyuluhan pertanian yang dilakukan oleh PPL Kelompok Gemah Rifah I dengan berbagai pertimbangan sehingga tujuan yang ingin dicapai berhasil. Mengingat alat bantu dan alat peraga penyuluhan terbatas di BPP, maka ini menjadi salah satu faktor teknis yang selalu dipertimbangkan.

Perkembangan kemampuan keterampilan anngota kelompoktani Gemah Rifah I juga menjadi pertimbangan. Yang paling utama model pendidikan penyuluhan adalah pendidikan orang dewasa. secara nonformal maka cara-cara komunikasi persuasif dikedepankan. Hal ini seperti dikatakan oleh Suwandi, (2006). Metode penyuluhan pertanian partisipatif yaitu masyarakat berpartisipasi secara interaktif, analisis-analisis dibuat secara bersama yang akhirnya membawa kepada suatu rencana tindakan. Partisipasi di sini menggunakan proses pembelajaran yang sistematis dan terstruktur melibatkan metode-metode multidisiplin, dalam hal ini kelompok ikut mengontrol keputusan lokal.

\section{Metode Berdasarkan Pendekatan Perorangan}


Metode penyuluhan pendekatan perorangan yang dilakukan oleh PPL yang bertugas di Kelompoktani Gemah Rifah I dengan cara bertemu secara langsung maupun tidak langsung dengan ketua kelompoktani dan anggota kelompoktani. Metode perorangan atau personal approach menurut Kartasaputra (dalam Setiana, 2005), sangat efektif digunakan dalam penyuluhan karena petani dapat secara langsung memecahkan masalahnya dengan bimbingan khusus dari penyuluh. Metode ini di Kelompoktani Gemah Rifah I jarang digunakan untuk menyampaikan materi penyuluhan. Oleh karena itu, jika dilihat dari segi jumlah sasaran yang ingin dicapai, metode ini kurang efektif karena terbatasnya jangkauan PPL untuk mengunjungi dan membimbing satu-satu Anggota Kelompoktani.

Metode pendekatan individu dilaksanakan oleh PPL yang bertugas di kelompoktani Gemah Rifah I hanya digunakan dalam mendekati orang-orang tertentu misalnya menelpon ketua kelompok untuk menyepakati pertemuan tertentu dengan kelompok. Bertemu dengan tokoh desa yang merupakan masyarakat yang berpengaruh untuk mencari mendukung keberadaan penyuluhan didesa. Mendekati anggota Kelompoktani yang sudah berhasil dan mengajak untuk memotivasi anggota lain, ada juga PPL mendekati ibu-ibu di Desa agar mendorong suaminya untuk ikut dalam kegiatan penyuluhan.

\section{Metode Berdasarkan Pendekatan Kelompok}

Dalam metode pendekatan kelompok

PPL Kelompoktani Gemah Rifah I berhungan langsung dengan semua anggota kelompok dalam pertemuan kelompoktani, baik itu menyampaikan materi, melakukan demontrasi cara dan memaparkan peta singkap tentang tahapan budidaya tanaman padi, jagung dan kedelai, memaparkan peta singkap tentang cara penanganan penyakit tanaman.

Pertemuan kelompoktani dilaksanakan bedasarkan jadwal kerja PPL mengacu pada jadwal LAKU yang mana jadwal tersebut dibuat melalui hasil kesepakatan antara PPL dan Petani untuk berkumpul. Hal ini tindak lanjut dari Permentan No.82/Permentan/ OT.140/8/2013 Tentang Pedoman Pembinaan Kelompoktani dan Gabungan Kelompoktani. Sistem Kerja Latihan dan Kunjungan serta supervisi yang selanjutnya disebut Sistem Kerja LAKU adalah pendekatan yang memadukan antara pelatihan bagi penyuluh dan ditindaklanjuti dengan kunjungan berupa pendampingan kepada petani/poktan secara terjadwal dan didukung dengan supervisi teknis dari penyuluh senior serta ketersediaan informasi teknologi sebagai materi kunjungan.

Tempat pertemuan Kelompoktani Gemah Rifah I terdiri dua tempat, pertama pertemuan dilaksanakan di Saung Tani dan di lapangan. Pertemuan Kelompoktani di Saung tani meruapakan pertemuan rutin. Dimana dalam pertemuan ini PPL menyampaikan materi yang sudah di sepakati bersama dengan anggota kelompoktani. Pertemuan di saung tani PPL menggunakan alat dan media penyuluhan berupa peta singkat. Penggunaan peta singkap dianggap oleh PPL lebih memudahkan petani mamahami tentang materi yang disampaikan. Seperti dijelaskan oleh Slamet (1995) Peta singkap adalah lembaran-lembaran kertas berisi gambar dan tulisan yang disusun secara berurutan, bagian atasnya disatukan sehingga mudah disingkap. Penyebaran materi menggunakan peta singkap ini bertujuan untuk menjelaskan suatu proses atau rangkaian 
kegiatan yang berkaitan dengan pertanian secara sistematis.Penyebaran materi penyuluhan melalui peta singkap ini akan efekif, bila disampaikan kepada kelopoktani dengan anggota antara 5-35 orang.

\section{Metode Berdasarkan Pendekatan Massal}

Metode pendekatan massal atau mass approach. cara ini dapat menjangkau sasaran dengan jumlah yang cukup banyak. PPL yang bertugas di Kelompoktani Gemah Rifah I melaksanakan metode ini tidak begitu sering. Karena metode ini sedikit membutuhkan dana dalam pengadaan alat dan medianya. Karena terbatas dana yang didukung oleh Pemda Aceh Tamiang, metode ini hanya dilaksanakan pada saat program yang dianggarkan oleh Pemerintah Daerah.

Pemutaran film membutuhkan dana banyak karena kegiatan ini laksanakan pada malam hari di lapangan bola desa Jamur Labu. Biaya yang dikeluarkan adalah untuk menyewa sound sistem, biaya makan minum penyuluh dan undangan para Pejabat Kecamatan. Pemuran Film penyuluhan di lapangan membutuhkan tenaga lebih dari satu PPL saja minimal 5 orang PPL. seperti penjelasan informan bahwa pemutaran film dilakukan pada saat sosialisai program baru Pemerintah seperti Padi Jagung dan Kedelai (PAJALE) barubaru ini dilaksanakan diseruluh kelompoktani dan pengenalan tehnologi baru. Kegiatan semacam ini dilaksanakan dan dianggarkan oleh Pemda.

Ditinjau dari segi penyampaian informasi, metode pendekatan massa cukup baik, namun terbatas hanya dapat menimbulkan kesadaran dan keingintahuan semata. Hal ini disebabkan karena pemberi dan penerima pesan cenderung mengalami proses selektif saat menggunakan media massa sehingga pesan yang disampaikan mengalami distorsi (Van den Ban dan Hawkins, 1999).

Berdasarkan hasil wawancara dan observasi, dari beberapa metode penyuluhan pertanian yang dijelaskan diatas, metode pendekatan kelompok dinilai lebih efektif dari pada metode pendekatan perorangan dan massal.

Efektifnya metode pendekatan kelompok dipandang oleh semua informan karena dalam pertemuan kelompok disana terjadi proses interaksi komunikasi langsung antara pihak yang terlibat dalam pertemuan kelompok. Interaksi antara PPL dalam menyampaikan materi dan meperagakan cara perlakuan teknologi anjuran pemerintah dengan semua anggota kelompoktani. Interaksi juga terjadi antara sesama anggota kelompok dalam menyampaikan tanggapan dan berdiskusi sesama dalam rangka menyatukan sikap, prilaku dan keterampilan dalam usaha tani. Sebagian anggota kelompok yang belum tau menjadi tau setelah mendengar dan bertanya baik kepada PPL dan kepada anggota lain. Sebagaimana pendapat Michael Burgoon (dalam Wiryanto, 2004), komunikasi dalam kelompok sebagai interaksi secara tatap muka antara tiga orang atau lebih, dengan tujuan yang telah diketahui, seperti berbagi informasi, menjaga diri, pemecahan masalah, yang mana anggota-anggotanya dapat mengingat karakteristik pribadi anggota-anggota yang lain secara tepat.

\section{KESIMPULAN}

Berdasarkan pengumpulan dan analisis data yang telah dilakukan, maka dapat disimpilkan;

1. Proses penerapan metode penyuluhan pertanian oleh PPL di kelompoktani Gemah Rifah I dimulai dari: Persiapan 
materi penyuluhan di Kelompoktani Gemah Rifah I mengacu pada kebutuhan lapangan. Alat bantu, alat peraga dan media penyuluhan yang disiapkan PPL bedasarkan minat dan kebutuhan Petani sehingga materi yang disampaikan oleh PPL betul-betul bermanfaat bagi anggota kelompoktani Gemah Rifah I.

2. Metode penyuluhan pertanian yang dilaksanakan oleh PPL kelompoktani Gemah Rifah I mengacu pada proses perubahan kognitif (pengetahuan) perubahan affektif (sikap), perubahan psikomotor (keterampilan). Untuk itu, PPL menggunakan komunikasi dengan pendekatan kelompok dengan cara pertemuan kelompok rutin. Selain itu, pada kelompoktani dengan kelas kelompok yang sudah tinggi, metode penyuluhan dengan pendekatan kelompok, yaitu kegiatan pertemuan rutin sangat efektif untuk pengembangan agribisnis petani.

3. Faktor-faktor dalam pemilihan metode penyuluh pertanian Kelompoktani Gemah Rifah I sebagai berikut:

a. Faktor keadaan petani dan layak secara teknis, dimana anggota Kelompoktani Gemah Rifah I mempunyai tingkat pengetahuan, sikap dan keterampilan sangat baik. Anggota kelompoktani Gemah Rifah I sudah mengikuti penyuluhan dalam waktu yang sangat lama maka motode penyuluhan disesuaikan dengan perkembangan kelas kelompoktani.

b. Faktor sosial dan agama Petani, dimana pemilihan materi dan metode penyuluhan yang diterapkan oleh PPL Kelompoktani Gemah Rifah I dengan menjunjung tinggi norma-norma sosial dan agama setempat. Sebuah teknologi sangat bermanfaat dan handal, tetapi bertentangan dengan normanorma sosial yang ada pada kelompoktani Gemah Rifah I maka teknologi itu dihindari oleh PPL karena dapat menyebabkan ketidakseimbangan sosial. Teknologi tersebut mesin panen padi sangat dilarang oleh kelompoktani Gemah Rifah I karena pola kerja usaha tani masih bersifat gotong royong sesama anggota kelompok.

Adapaun saran yang hendak peneliti ungkapkan sebagai berikut:

1. kepada peneliti selanjutnya agar memperkaya teori tentang komunikasi kelompok terutama menyangkut dinamika komunikasi dikelompoktani, yang mana karakteristik tempat penelitian ini belum bisa menggambarkan secara umum pada kelompok lain di wilayah yang berbeda. nasional.

2. Penelitian lain tentang metode komunikasi penyuluh pertanian untuk kemajuan kelompoktani sehingga dapat dijadikan rujukan karena sebagian kecil telah ditemukan dalam penelitian ini. Peneliti selanjutnya dapat melihat dengan cara pandang dan tujuan yang lain. sehingga dapat berguna bagi kelompoktani lain dan pemerintah daerah dalam pemberdayaan masyarakat.

3. Perlu adanya persiapan penyuluhan yang matang, kesiapan alat bantu dan alat peraga yang memadai serta terus menggali potensi lain di Kelompoktani Gemah Rifah I sehingga usaha tani kelompok bisa lebih berkembang.

4. Petani mengalamai kendala dalam pengelolaan hasil panen, dimana 
sampai saat ini anggota kelompoktani masih menjual gabah basah. Untuk itu, dapat dilakukan udaha-usaha seperti; membuat permohonan kepada pemerintah, melakukan studi banding ke luar daerah guna terbuka wawasan bagaimana cara pengelolaan usaha tani mulai dari hilir sampai kehulu, melakukan demontrasi cara tentang pengelolaan dan penanganan hasil panen.

5. Perlunya peningkatan kerja sama kelompoktani dengan pihak lain dalam rangka pengembangan usaha tani lebih baik.

6. Perlu adanya dukungan dana dari Pemerintah setempat agar tersedia sarana dan prasana pendukung kegiatan penyuluhan pertanian.

\section{DAFTAR PUSTAKA}

Arikunto, Suharsimi. (2002). Prosedur Penelitian Suatu Pendekatan Praktek. Jakarta: PT Rineka Cipta.

Bungin, Burhan. (2006). Sosiologi Komunikasi: Teori, Paradigma dan Diskursus Teknologi Komunikasi di Masyarakat. Jakarta: Kencana Prenada Media Group

Creswell, J. W., and Clark, Vicky, L. P.(2007). Designing and conducting mixed methods research. Thousand Oaks, CA: Sage Publications.

Daymon, C. \& Holloway, I. (2008). Riset kualitatif dalam public relations\&marketing communications (Cahya Wiratama, Penerjemah). Yogyakarta: PT. Bentang Pustaka.

Dwihayanti. (2004). Faktor-Faktor Komunikasi Yang Berhubungan Dengan Kinerja Kelompok PetaniNelayan Kecil (KPK). Tesis (S2). Bogor: Institut Pertanian Bogor.
Depari, E dan MacAndrews, D. Colin. (1978). Peranan komunikasi massa dalam pembangunan. Yogyakarta: Gadjah Mada University Press.

Effendy, Onong. (1995). Ilmu Komunikasi (teori dan praktek). Bandung: PT Remaja.

Far F, Risyart, A. (2014). Respon Petani Terhadap Penerapan Metode Penyuluhan Pertanian Di Kota Ambon Provinsi Maluku. Jurnal Vol. 10. Ambon: Universitas Patimura.

Gunawan, Handoko dan Rika Asnita. (2008). Peningkatan Keuntungan Usahatani Kedelai Melalui PTT di Kabupaten Bojonegoro. Jawa Timur, diambil dari: http://karyailmiah.um.ac.id

Goldberg, Alvin dan Larson, Carl. (2006). Komunikasi Kelompok. Jakarta: Penerbit Universitas Indonesia.

Oktaviani, Erlita. (2007). Peranan Penyuluh Pertanian Dalam Pengembangan Kelompok Tani Di Kecamatan Junrejo Kota Batu. Tesis (S2). Malang: Universitas Muhammadiyah Malang.

Samsudin. (1982). Dasar Penyuluhan dan Modernisasi Pertanian. Bandung: Bina Cipta.

Silalahi, Ulber. (2009). Metode Penelitian Sosial. Bandung: PT. Refika Aditama.

Sudjarwo dan Basrowi. (2009). Manajemen Penelitian Sosial. Bandung: CV. Mandar Maju..

Sumardjo. (1999). Transformasi Model Penyuluhan Pertanian Menuju Pengembangan Kemandirian Petani. Kasus di Propinsi Jawa Barat. Disertasi (S3). Bogor: Institut Pertanian Bogor.

Suparta, N. (2001). Perilaku Agribisnis dan Kebutuhan Penyuluhan Peternak 
Ayam Ras Pedaging. Disertasi (S3).

Bogor: Institut Pertanian Bogor.

Suprapti Supardi, Djiwandi, Priyo Prasetyo,

(1991). Pengantar Ekonomi

Pertanian: Departemen Pendidikan

Dan Kebudayaan Republik

Indonesia, Surakarta: Universitas

Sebelas Maret.

Suryana, A. dan Ketut, K. (2008). Ekonomi

Padi Asia: Suatu Tinjauan Berbasis

Kajian Komparatif. Jurnal Vol 25.

Bogor: Balai Besar Pengembangan

dan Pengkajian Tekhnologi

Pertanian.

Suriatna, S. (1987). Metode Penyuluhan Pertanian. Jakarta: PT Medyatama Sarana Perkasa

Suwandi. (2006). Penyuluhan Partisipatif. Bogor: Cekza Blog.

Sumardjo. (1999). Transformasi Model Penyuluhan Pertanian Menuju Pengembangan Kemandirian Petani (Kasus di Propinsi Jawa Barat). Disertasi (S3). Bogor: Institut Pertanian Bogor.

Suriapermana S, N Indah, dan Y Surdianto. (2000). Teknologi budidaya padi dengan cara tanam legowo pada lahan sawah irigasi. Jurnal Vol. 125135. Bogor: Pusat Penelitian dan Pengembangan Tanaman Pangan.

Soewardi, Herman. (1976). Sikap masyarakat Desa Terhadap Modernisasi produksi Pertanian, terutama padi. Jawa Barat : Gajah Madha University Press.

Slamet, Margono. (2001). Perspektif Ilmu Penyuluhan Pembangunan Menyongsong Era Tinggal Landas dalam Penyuluhan Pembangunan di Indonesia: Menyongsong Abad 21. Jakarta: PT Pustaka Pembangunan Swadaya Nusantara.
Van den Ban. A.W. dan H.S Hawkins, (2011). Penyuluhan Pertanian. Yogyakarta: Kanisius.

Wijianto, Arif. (2005). Metode dan Teknik Penyuluhan Pertanian. Surakarta: Fakultas Pertanian UNS.

Wiraatmaja, Sukandar. (1983). Penyuluhan Pertanian. Jakarta: Departemen Pendidikan dan Kebudayaan.

Wiryanto. (2004). Pengantar Ilmu Komunikasi. Jakarta: PT Grasindo.

Wolf, Erik. (1985). Petani Suatu Tinjauan Antropologis. Jakarta: Rajawali.

Yin, Robert, K (2003). Applications of Case Study Research 2nd Thousand Oaks, CA: Sage Publications edition.

Zulkifli. (2009 Januari 9). Analisis Efisiensi Penggunaan Faktor Produksi pada Usahatani Jagung Studi Kasus Petani Jagung di Kel, Panreng Kec. Sidrap Tabloid Sinar Tani. 